Дитяча стоматологія

УДК 616.314-002-053.2(477.87-22)

DOI

(В. С. Мельник, Л. Ф. Горзов, О. В. Когут

ДВНЗ «Ужгородський національний університет»

\title{
Оцінка ризику розвитку карієсу зубів у дітей в сільській місцевості
}

Резюме. Було проведено дослідження поширеності та інтенсивності карієсу зубів у дітей молодшого шкільного віку в сільській місцевості. Вивчення питання прогнозування та оцінки ризику виникнення карієсу в дітей є актуальною проблемою, тому що на підставі цих даних можна визначити потребу дитячого населення в лікувальних і профілактичних заходах, розрахувати необхідний обсяг стоматологічної допомоги, оцінити ефективність лікувально-профілактичних заходів.

Ключові слова: карієс зубів, профілактика, діти, сільська місцевість.

\author{
В. С. Мельник, Л. Ф. Горзов, О. В. Когут
}

ГВУЗ «Ужгородский национальный университет»

\section{Оценка риска развития кариеса зубов у детей в сельской местности}

Резюме. Было проведено исследование распространенности и интенсивности кариеса зубов у детей младшего школьного возраста в сельской местности. Изучение вопроса прогнозирования и оценки риска возникновения кариеса у детей является актуальной проблемой, так как на основании этих данных можно определить потребность детского населения в лечебных и профилактических мероприятиях, рассчитать необходимый объем стоматологической помощи, оценить эффективность лечебно-профилактических мероприятий.

Ключевые слова: кариес зубов, профилактика, дети, сельская местность.

\author{
V. S. Melnyk, L. F. Horzov, O. V. Kohut
}

SHEI «Uzhgorod National University»

\section{Evaluation of the risk of tooth decay among children in the countryside}

Summary. There was conducted a study of the prevalence and intensity of dental caries in primary school children in rural areas. Study of prediction and assessment of the risk of tooth decay in children is an urgent problem, because on the basis of these data, we can determine the child population in need of treatment and preventive measures, calculate the necessary amount of dental care, to assess the effectiveness of preventive measures.

Key words: dental caries, prevention, children, countryside.

Вступ. Незважаючи на певні успіхи у профілактиці захворювань карієсу зубів в Україні, реєструють його високу поширеність та інтенсивність, особливо серед дитячого населення, що залишається актуальною проблемою сучасної стоматології
[1]. На сьогодні є багато робіт із профілактики карієсу зубів. Незважаючи на те, що накопичений великий позитивний досвід щодо впровадження превентивних заходів, рівень стоматологічної захворюваності не знижується. Актуальність розробки 
методів профілактики також пов'язана зі зменшенням обсягу лікувальних заходів i, як наслідок, матеріальних затрат, так як вартість профілактичних методів у 20 разів нижче вартості лікування захворювання [4, 6].

Одним 3 основних показників прогнозування виникнення та перебігу каріозного процесу вважають показник КПВ або КПВ+Кп. На підставі середнього значення сумарного показника КПВ+кп Т. Ф. Виноградова, як критерій оцінки активності карієсу, прогнозування його розвитку запропонувала у дітей та підлітків розрізняти 3 форми перебігу карієсу зубів. Цей критерій підтверджений практикою проведення організованої санації порожнини рота у дітей [3]. До факторів, що виявляють “слабку ланку» в ланцюзі виникнення карієсу зубів або протистоять його розвитку, належать тести, які характеризують вираження етіологічного характеру в слині, лактобацилярний тест, гігієнічні індекси), стійкість емалізубів до діїкислотіздатність до ремінералізації, властивості ротової рідини (iї в'язкість, буферна ємність, $\mathrm{pH}$, швидкість слиновиділення) [5, 9].

На жаль, не всі методи прогнозування карієсу доступні у сільській місцевості через недостатність фінансування та складності у виконанні методів дослідження. Складання програм групової та індивідуальної профілактики карієсу зубів у дітей на основі прогнозування та оцінки ризику виникнення може сприяти зниженню інтенсивності й поширеності даної патології [8]. Це і визначило мету та завдання даного дослідження. Необхідно вибрати найбільш інформативні й фінансово доступні методи прогнозування виникнення карієсу зубів в умовах сільської місцевості.

Метою дослідження була розробка та оцінка ефективності комплексу методів із прогнозування ризику виникнення і розвитку карієсу в дітей молодшого шкільного віку в умовах сільської місцевості села Березинка Мукачівського району.

Матеріали і методи. Відповідно до мети та завдань, ми провели дослідження поширеності та інтенсивності карієсу зубів у дітей молодшого шкільного віку в умовах сільської місцевості з урахуванням впливу факторів ризику; особливості мікробіологічної характеристики зубних відкладень із різними формами карієсу зубів; рівня гігієни порожнини рота у віковому аспекті; визначені короткотривалий і довготривалий прогнози ризику розвитку різних форм карієсу зубів у дітей шляхом складання скринінг-тесту. Програма дослідження включала в себе проведення комплексних стоматологічних досліджень-оцінку гігієни порожнини рота, інтенсивності та поширеності карієсу зубів, рівень інтенсивності карієсу, метод виявлення груп населення 3 найвищою інтенсивністю карієсу зубів: визначення індексу «Найвища інтенсивність карієсу»SIC, мікробіологічне дослідження зубних відкладень, анкетування. Було обстежено 215 дітей у віці 7-8 років. Основні показники стоматологічного статусу в обстежених дітей представлені в таблиці.

Результати досліджень та їх обговорення. Стоматологічне обстеження пацієнтів здійснювали за загальноприйнятим алгоритмом ВОО3 [2]. Дані спостережень

Таблищя. Показники стоматологічного статусу в обстежених дітей

\begin{tabular}{|l|l|}
\hline \multicolumn{1}{|c|}{ Метод дослідження } & \multicolumn{1}{c|}{ Показник } \\
\hline Анкетування батьків & Резистентність організму дитини \\
\hline Клінічний огляд, збір анамнезу & Виявлення факторів ризику розвитку карієсу \\
\hline $\begin{array}{l}\text { Забір зубного нальоту проводили натще, до } \\
\text { ранкового чищення зубів }\end{array}$ & Вивчення видового складу мікроорганізмів зубного нальоту \\
\hline Індекс гігієни порожнини рота ОНІ-S & Оцінка гігієнічного стану порожнини рота \\
\hline У \% від числа обстежених & Поширеність карієсу \\
\hline Індекс КПВ+кп, РІК & Iнтенсивність та активність карієсу \\
\hline Індекс НІК & $\begin{array}{l}\text { Significant Index of Сaries } \\
\text { Найвища інтенсивність карієсу }\end{array}$ \\
\hline
\end{tabular}


фіксували в картах обстеження стану порожнини рота у дітей. Обстеження дитини починали із з'ясування анамнестичних даних у батьків. Фіксували такі дані: вік батьків, особливо матері на момент народження дитини, шкідливі звички, соціальний статус, місце проживання, а також соматичні захворювання батьків. Ми ретельно аналізували фактори ризику, які мають істотний вплив на формування систем і органів майбутньої дитини, у тому числі на зубощелепну систему.

Відповідно до вищесказаного, ми виділили основні фактори ризику, що впливають на здоров'я майбутньої дитини: спадкові захворювання як по материнській, так і по батьківській лінії, хронічні та гінекологічні захворювання матері, вірусні захворювання під час вагітності та прийом лікарських засобів у даний період, терміни народження дітей, а також рівень здоров'я при народженні й тип вигодовування дитини.

Особливу увагу приділяли аналізу акушерського анамнезу, а саме: які за порядком вагітність та пологи; вік породіль; наявність або відсутність патологій перебігу вагітності, таких, як гестози, загроза переривання вагітності (обов'язково вказували період прояву цих патологій); перебіг пологів; гострі та хронічні загальносоматичні захворювання.

При з'ясуванні анамнестичних даних дітей, обстежених нами, акцентували увагу на стан і перинатального періоду, супутніх і перенесених захворюваннях у дитини, з'ясовували характер вигодовування дитини та її терміни, з якого віку вводили прикорм у раціон харчування i які були переваги в їжі.

Збирали інформацію про терміни прорізування зубів, соматичний статус дитини в даний період, про шкідливі звички (тривале смоктання соски і нічне годування $з$ пляшечки), а також з якого віку дитина самостійно або за допомогою батьків стала проводити гігієну порожнини рота [7].

Проведене стоматологічне обстеження дітей молодшого шкільного віку в сільській місцевості показало, що у середньому рівень гігієни порожнини рота за індексом OHI-S має незадовільну оцінку. Поділ дітей у цій віковій категорії за оцінкою гігієни порожнини рота представлено на рисунку 1.

Як видно 3 рисунку, порівну розподіляються діти семирічного віку (по 45 осіб по 44,6 \% від загального числа обстежених) із задовільною та незадовільною гігієною порожнинирота.Добругігієнупорожнини рота визначено у 5 дітей, що становить 4,9 \% від загальної кількості обстежених у даній групі. Погану гігієну порожнини рота виявлено у 6 дітей семирічного віку, що становить 5,9 \% від загальної кількості обстежених.

Більшість дітей восьмирічного віку (59 осіб - 51,8 \% від загального числа обстежених) має незадовільну гігієну порожнини рота. Діти, у яких гігієна

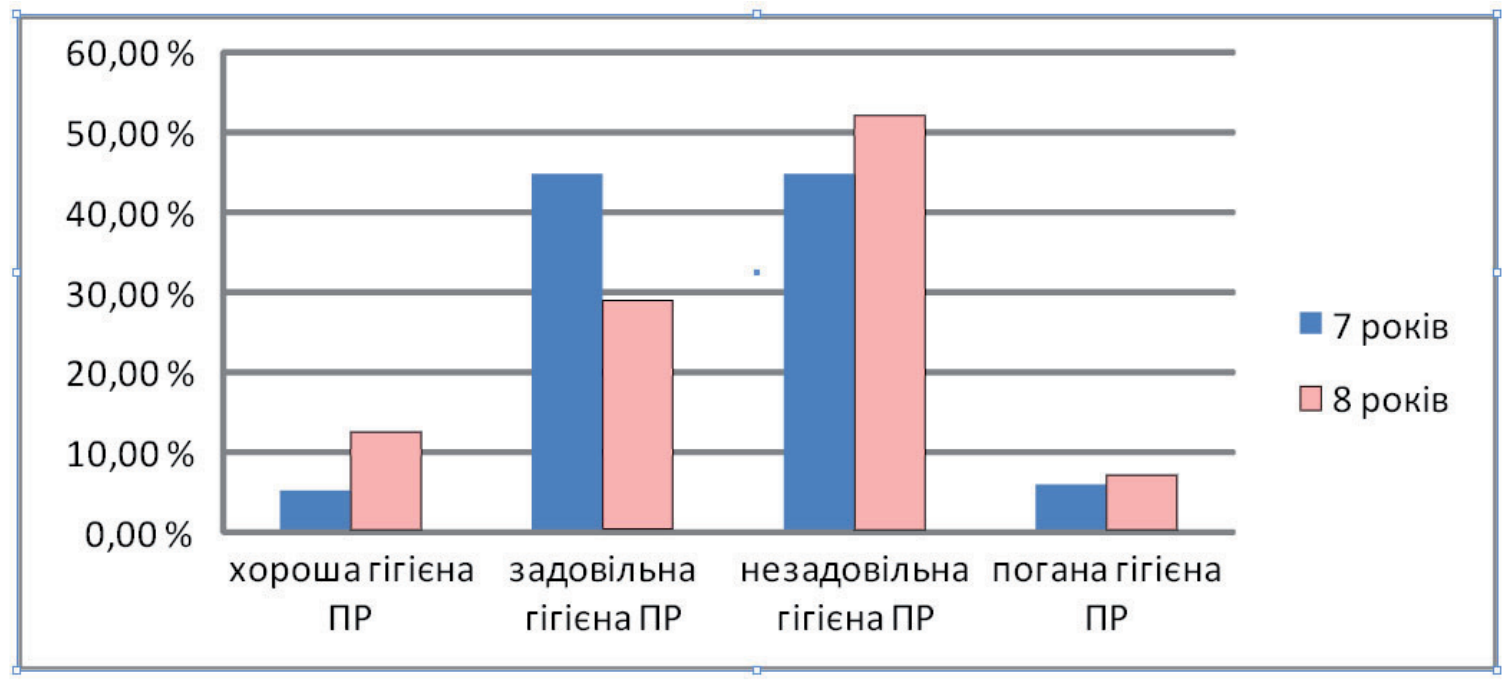

Puc. 1. Поділ дітей за оцінкою гігієни порожнин рота. 
порожнини рота на задовільному рівні, склали 33 особи, що становить 28,9 \% від загального числа обстежених. Добру гігієну порожнини рота визначено у 14 дітей, що сскладає 12,3 \% від загальної кількості обстежених у даній групі дітей. Погана гігієна порожнини рота була у 8 дітей, що становить 7,1 \% від загального числа обстежених.

Проведене мікробіологічне дослідження зубного нальоту в дітей даної вікової категорії показало такі результати. У групі дітей із високою інтенсивністю карієсу видовий склад мікрофлори зубного нальоту був представлений мікроорганізмами: Lactobacillus, Streptococcus salivarius, Streptococcus mutans, Streptococcus sangius, Streptococcus mitis i Streptococcus agalactiae; Staphylococcus haemolyticus, Staphylococcus aureus i Staphylococcus epidermidis; Enterococcus faecium та гриби роду Candida.

Видовий склад мікроорганізмів у зубному нальоті в дітей із високою інтенсивністю карієсу не відрізнявся від тих же видів мікроорганізмів зубного нальоту в дітей із середньою інтенсивністю карієсу. У 100 \% випадків було виявлено мікроорганізми: Lactobacillus spp., Streptococcus salivarius, Streptococcus sanguis, Streptococcus mitis, Streptococcus mutans. Гриби роду Candida spp. - у 22,6 \% випадків, а Enterococcus faecium в $16,12 \%$.

Проведене стоматологічне обстеження показало високу поширеність каріозного процесу серед усіх обстежених нами дітей молодшого шкільного віку в сільській місцевості. Найбільш високий показник поширеності карієсу зубів було виявлено у восьмирічних дітей - $81 \%, 78 \%$ - у дітей семирічного віку. Інтенсивність карієсу в обстежених дітей даної групи за індексом КПВ+кп відповідно склала 4,95 \pm ,13 і 4,32 $\pm 3,89$, що є досить високим показником.

Проте середній КПВ зубів не відображає повної картини розподілу карієсу зубів серед обстежених груп дітей. За допомогою індексу "найвища інтенсивність карієсу» (НIК), який ми застосовували у нашій роботі вперше, вдалося виявити групи дітей молодшого шкільного віку в сільській місцевості 3 найвищими значеннями КПВ зубів.
НІК обчислювали таким чином. Опрацьовану вікову групу розподіляли згідно із значеннями КПВ зубів у зростаючому порядку. Потім одну третину обстежуваних, яка мала найвищі значення КПВ, виділяли в окрему групу. В цій групі обчислювали середнє значення КПВ зубів, яке і було індексом НІК. Вперше встановлено, що НІК у віковій групі дітей семи років склав 7,43 $\pm 2,64$, разом 3 тим, як середній КПВ зубів був $4,32 \pm 3,89$ ( $<<0,05)$. НІК у віковій групі дітей 8-ми років склав відповід-

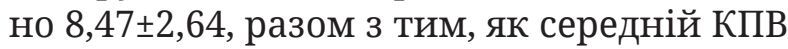
зубів був $4,95 \pm 4,13(\mathrm{p}<0,05)$.

Рівень інтенсивності карієсу зубів (РІК) у семирічних дітей становив: низький рівень інтенсивності карієсу тимчасових зубів виявлено у 16 дітей, що склало 15,8 \% від кількості обстежених, середній рівень інтенсивності карієсу тимчасових зубів 50,5 \% (51 дитина), високий рівень - 22,8 \% (23 дитини), дуже високий рівень інтенсивності карієсу тимчасових зубів - $1 \%$ (1 дитина), у 10 (9,9 \%) обстежуваних дітей виявлено інтактні зубні ряди.

Рівень інтенсивності карієсу постійних зубів виглядає таким чином. Низький рівень інтенсивності карієсу постійних зубів виявлено у 46 дітей, що становить 45,5 \% від кількості обстежених семирічних дітей, середній рівень інтенсивності карієсу постійних зубів - 26,7 \% (27 дітей), високого рівня інтенсивності карієсу постійних зубів не виявлено, дуже високий рівень інтенсивності карієсу постійних зубів - 16,8 \% (17 дітей). Розподіл семирічних дітей, залежно від рівня інтенсивності карієсу тимчасових і постійних зубів, представлено на рисунку 2.

Як показав аналіз РІК, у восьмирічних дітей, низький рівень інтенсивності карієсу тимчасових зубів виявлено у 31 дитини, що становить 27,2 \% від кількості обстежених, середній рівень інтенсивності карієсу тимчасових зубів - 53,5 \% (61 дитина), високий рівень - 5,3 \% (6 дітей), дуже високий рівень інтенсивності карієсу тимчасових зубів - 1 \% (1 дитина), у 15 обстежуваних дітей (13,2 \%) виявлено інтактні зубні ряди. Рівень інтенсивності карієсу постійних зубів виглядає таким чином: низький рівень інтенсивності карієсу по- 
Дитяча стоматологія

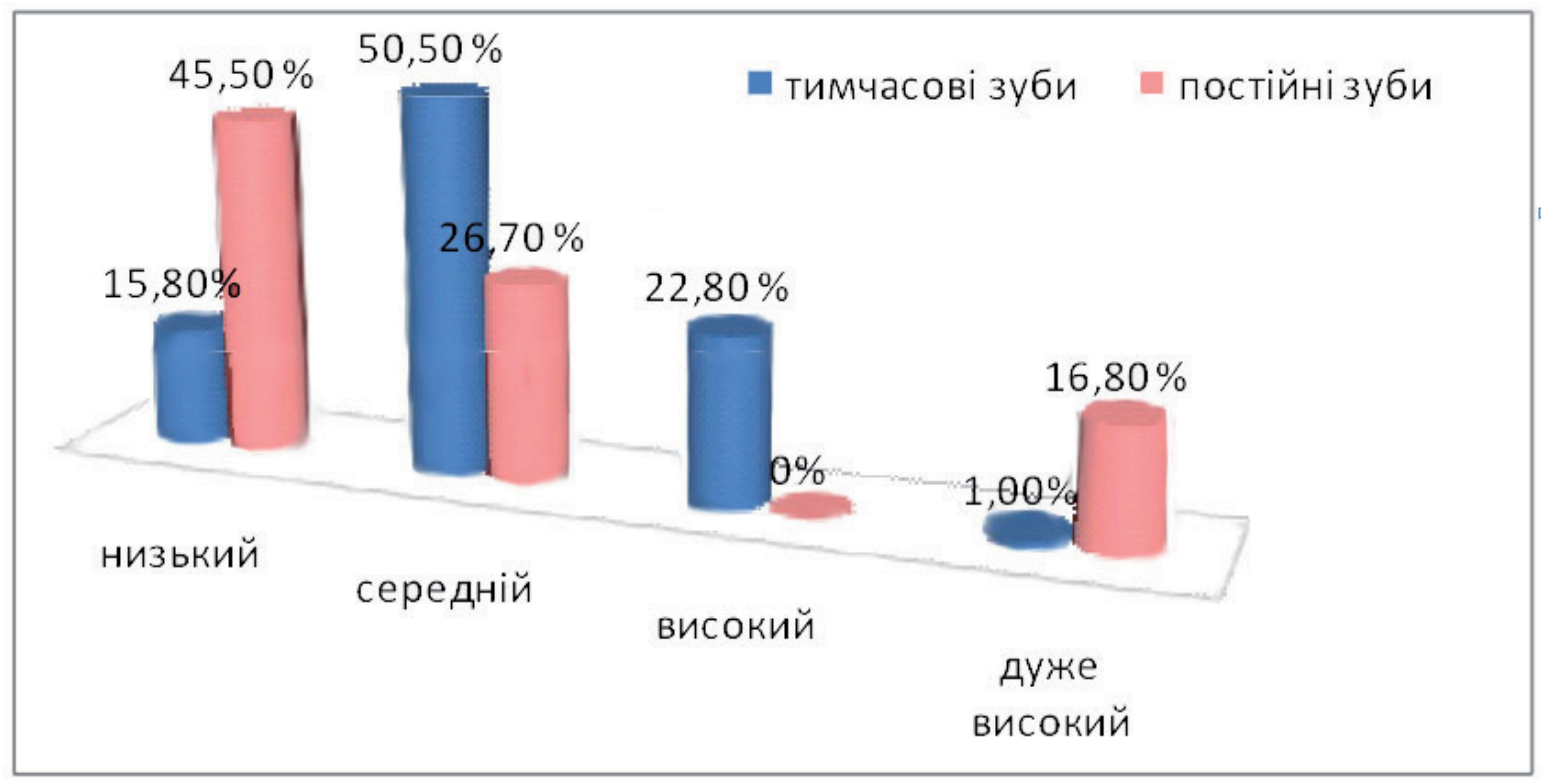

Puc. 2. Рівень інтенсивності карієсу тимчасових і постійних зубів у дітей 7 років.

стійних зубів був у 59 дітей, що становить 51,8 \% від кількості обстежених восьмирічних дітей, середній рівень інтенсивності карієсу постійних зубів - 14 \% (16 дітей), високий рівень - 20,2 \% (23 дитини), дуже високий рівень інтенсивності карі- єсу постійних зубів - 0,9 \% (1 дитина). Поділ дітей залежно від РІК тимчасових і постійних зубів представлено на рисунку 3.

Висновки. Аналізуючи вищесказане, можна зауважити, що карієсогенна ситуація може складатися із різних факторів

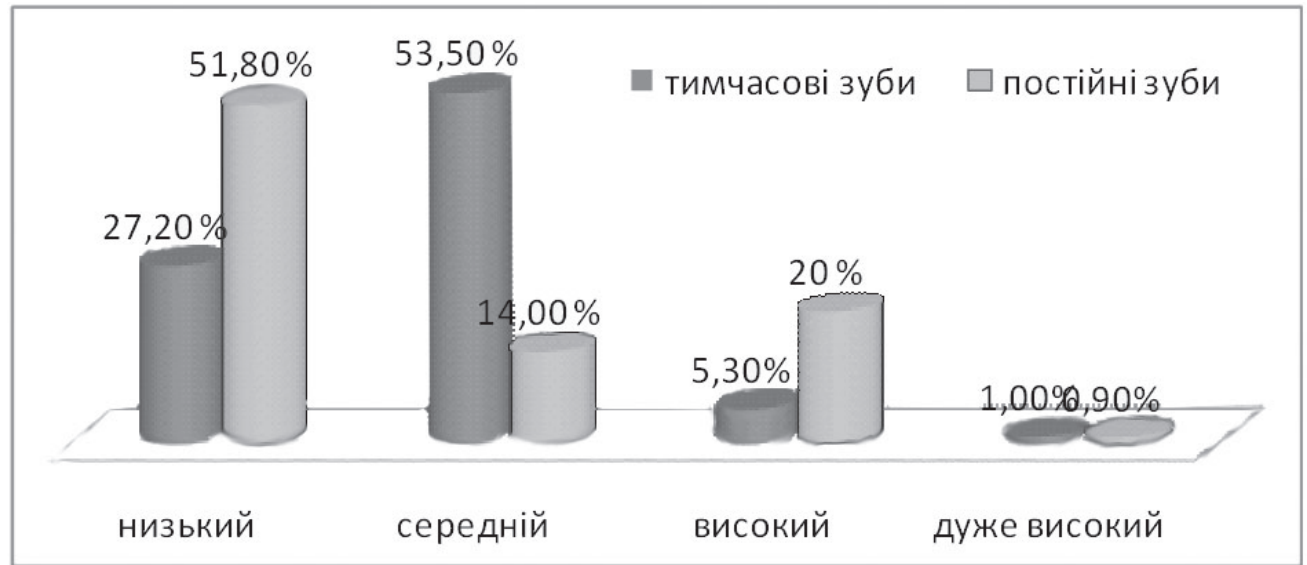

Puc. 3. Рівень інтенсивності карієсу тимчасових і постійних зубів у дітей восьми років.

ризику як загального, так і місцевого характеру. Карієс зубів з'являється у тому випадку, коли сила впливу карієсогенної ситуації в порожнині рота перевищує стійкість зуба до несприятливих чинників. Під впливом різних загальносоматичних захворювань змінюються умови формування і дозрівання твердих тканин зуба, що робить їх менш стійкими при впливі карієсогенних факторів. Одним iз перспективних напрямків підвищен- ня ефективності протикаріозних заходів $є$ виділення груп ризику, які потребують більшого обсягу карієсопрофілактичних впливів.

Своєчасне виявлення найбільш сприйнятливих дітей для проведення необхідних лікувально-профілактичних заходів дозволяє запобігти прогресуванню захворювання. Тому разом із масовими методами профілактики карієсу необхідний індивідуальний підхід до надання 
лікувально-профілактичної допомоги дитячому населенню. Вивчаючи сучасні методи прогнозування карієсу зубів у дітей, необхідно зважати на їх клінічні, соціальні та економічні складові.

Таким чином, упроваджують програми профілактики стоматологічних захворювань 3 метою зниження інтенсивності карієсу зубів і захворювань тканин пародонта, зменшення випадків втрати зубів

\section{Список літератури}

1. Біденко Н. В. Ранній карієс у Україні та у світі / Н.В.Біденко // Современная стоматология. -2007.№ 1. - С. 66-72.

2. Бюллетень ВОЗ «Стоматологическое обследование, основные методы». - 3-е изд. - Женева, 1989. - C. 21.

3. Виноградова Т. Ф. Диспансеризация детей у стоматолога / Т. Ф. Виноградова. - М. : Медицина, 1990. -183 c.

4. Жан-Франсуа Руле Профессиональная профилактика в практике стоматолога / Жан-Франсуа Руле, Стефан Циммер. М. : МЕДпресс-информ, 2010. - С. 90-91.

5. Кисельникова Л. П. Современные возможности профилактики кариеса зубов у детей раннего возраста / Л. П. Кисельникова, Н. В. Вагеманс // Педиатрия. - 2010. -Т. 89, № 5. - С. 130-136. у молодому віці й зростання кількості 3 інтактними зубами. Складання програми індивідуальної профілактики карієсу зубів у дітей молодшого шкільного віку на основі найбільш інформативного та фінансово доступного методу прогнозування виникнення карієсу в умовах сільської місцевості сприяє зниженню приросту карієсу, інтенсивності та поширеності даної патології у віковому аспекті.

6. Кузьмина Э. М. Профилактика стоматологических заболеваний : учебное пособие. Полимедиап-ресс, 2001. - 216 с.

7. Мельник В. С. Результати анкетування дітей, проведеного в рамках виконання програми «Здорова усмішка дітей Закарпаття» / В. С. Мельник, Л. Ф. Горзов // Молодий вчений. - 2014. - № 9. С 128-130.

8. Скатова Е. А. Практические аспекты определения риска развития кариеса / Е. А. Скатова, М. К. Макеева, А. А. Шакарьянц // ДенталЮг. 2010. - № 6. - C. 24-25.

9. Loe $\mathrm{H}$. Oral hygiene in the prevention of caries and periodontal disease / H. Loe // Int. Dent. J. - 2000. Vol. 50(3). - P. 129-139. 